ZalǫcZnilf

DOI 10.21697/zk.2020.7.14

\title{
MARLENE DIETRICH I THE MILLIONAIRE WALTZ QUEEN. JEZZYKOWO-MUZYCZNE KONSTRUKCJE PERSONY W MUZYCE POPULARNEJ
}

MARIUSZ GRADOWSKI

Monika Konert-Panek
Instytut Muzykologii UW

Institute of Musicology, University of Warsaw

mariusz.gradowski@uw.edu.pl

ORCID: 0000-0002-1941-4073
Instytut Komunikacji Specjalistycznej i Interkulturowej UW Institute of Specialised and Intercultural Communication, University of Warsaw m.konert@uw.edu.pl ORCID: 0000-0002-1463-3357

Pojęcie persony odgrywa istotną rolę zarówno w teoriach muzykologicznych, jak i lingwistycznych, a choć rozumiane bywa różnorako, zauważyć można pewne części wspólne tych obszarów badawczych. Z perspektywy językoznawczej pojęcie to nabrało szczególnego znaczenia w tzw. trzeciej fali socjolingwistyki $\mathrm{i}^{1}$, stanowiącej najnowszy trend badawczy w tej dyscyplinie. W odróżnieniu od nurtów wcześniejszych, tj. pierwszej fali, skoncentrowanej na całych społecznościach i ich stratyfikacji społeczno-ekonomicznej, czy też drugiej fali, badającej kategorie lokalne z zastosowaniem metod etnograficznych, trzecia fala socjolingwistyki podkreśla rolę jednostki w kreowaniu znaczeń społecznych poprzez stosowanie określonych cech językowych. Stąd odnowione zainteresowanie pojęciami takimi jak styl bądź stylizacja czy też ogólnie: sposób, w jaki jednostka tworzy znaczenia i konstruuje daną tożsamość lub personę, wybierając określone formy językowe $\mathrm{z}$ dostępnego repertuaru wariantów - w ten sposób jednostka może niejako wyrwać się ze skonwencjonalizowanych znaczeń społecznych poszczególnych dialek-

1 P. Eckert, Variation and the Indexical Field, „Journal of Sociolinguistics” 2008, Vol. 12, No. 4; idem, Meaning and Linguistic Variation. The Third Wave in Sociolinguistics, Cambridge 2018. 
tów lub akcentów. W badaniach socjolingwistycznych pojawiają się w tym kontekście grupy społeczne takie jak valley girls, bitnicy czy gejowskie divy. Również - a może nawet: tym bardziej - w socjolingwistycznych analizach muzyki popularnej podkreśla się rolę czynnika twórczego w konstruowaniu określonych znaczeń, wizerunków i person, a kontestowaniu innych (np. persona sheffieldzka Alexa Turnera z Arctic Monkeys w analizie Joan Beal²).

Z kolei muzykologiczna teoria persony muzycznej to jedna $\mathrm{z}$ wielu koncepcji badania i rozumienia dzieła muzycznego. Jako model poznawczy i narzędzie zarysowana została w pracy The Composer's Voice Thomasa Cone'a ${ }^{3}$, a rozwinięcie znalazła u Jerrolda Levinsona ${ }^{4}$ i Jenefer Robinson ${ }^{5}$. Jak pisze Karolina Kolinek-Siechowicz, istotą teorii persony muzycznej jest „figura wyimaginowanego podmiotu będącego nośnikiem emocji muzycznych i pośrednikiem między kompozy torem/wykonawcą a odbiorcą"6. Takie postrzeganie persony muzycznej związane jest przede wszystkim z badaniem tzw. muzyki poważnej i dotyczy głównie muzyki absolutnej. Ponieważ tworzy nakładany na dźwięki konstrukt znaczeniowy, teoria persony muzycznej jest krytykowana, czego najlepszym przykładem są studia Petera Kivy’ego ${ }^{7}$ czy rozwijającej jego myśl Anny Chęćki-Gotkowicz ${ }^{8}$.

Badania nad muzyką popularną również korzystają z koncepcji persony muzycznej. Odmienna specyfika tzw. muzyki poważnej i muzyki popularnej (m.in. forma i funkcja kompozycji, język kompozytorski, estetyka, relacje:

2 J. Beal, „You're not from New York City, you're from Rotherham”: Dialect and Identity in British Indie Music, „Journal of English Linguistics” 2009, Vol. 37, No. 3.

3 E.T. Cone, The Composer's Voice, Berkeley 1974.

4 J. Levinson, Music, Arts \& Metaphysics. Essays in Philosophical Aesthetics, Ithaca (NY) - London 1990.

5 J. Robinson, Deeper than Reason, Emotion and its Role in Literature, Music, and Art, Oxford 2005.

${ }^{6}$ K. Kolinek-Siechowicz, Od teorii muzycznej persony do muzycznego personali$z m u$, [w:] Peter Kivy i jego filozofia muzyki, red. A. Chęćka-Gotkowicz, M. Jabłoński, Poznań 2015, s. 237.

7 P. Kivy, Antithetical Arts: On the Ancient Quarrel Between Literature and Music, Oxford 2009.

8 A. Chęćka-Gotkowicz, Persona (non) grata : czy muzyka absolutna potrzebuje narratora?, „Aspekty Muzyki” 2013, nr 3. 
nadawca - wykonawca - odbiorca, zapis partyturowy i jego realizacja a nagranie jako prymarny poziom istnienia utworu) sprawia, że status persony muzycznej w muzyce popularnej jest znacznie bardziej uchwytny, jej badanie zasadne i przydatne, a sama teoria nie budzi kontrowersji. Pokazują to m.in. prace Simona Fritha ${ }^{9}$ czy Philipa Auslandera ${ }^{10}$, a także, szczególnie interesująco, książka Allana F. Moore’a Song Means: Analysing and Interpreting Recorded Popular Song ${ }^{11}$. W rozdziale zatytułowanym Persona Moore bada relacje komunikacyjne i poziomy znaczeniowe wynikające z nieciągłości zachodzących między: (a) śpiewającym człowiekiem (performerem), (b) jego śpiewem (nagranym lub live) poddanym zabiegom brzmieniowo-stylizacyjnym i konstytuującym muzyczną personę nie zawsze tożsamą ze śpiewającym człowiekiem, a także (c) tworzącej się w nagranym śpiewie (lub możliwej do zaistnienia) postaci śpiewającej, będącej - niczym podmiot liryczny bądź osoba dramatu - bohaterem danego utworu ${ }^{12}$. O ile można zgodzić się z Kivym, że w muzyce absolutnej sztuka dźwięku odrywa się od personalizacji, o tyle w przypadku muzyki popularnej uchwytne personalizacje może tworzyć rozwarstwienie zarysowanych przez Moore’a poziomów znaczeń. Domyślnym punktem wyjścia jest bowiem w muzyce popularnej możliwa bliskość lub wręcz tożsamość tych poziomów - tak jest np. w każdej nagranej wersji utworu Czas jak rzeka, napisanego i śpiewanego przez Czesława Niemena: jej odbiór nie ujawnia żadnych cech wskazujących na narracyjno-semantyczne pęknięcia, a historyk muzyki potwierdza

9 S. Frith, Sceniczne rytuały. O wartości muzyki popularnej, tłum. M. Król, Kraków 2011.

10 P. Auslander, Musical Persona: The Physical Performance of Popular Music, [w:] The Ashgate Research Companion to Popular Musicology, ed D.B. Scott, Farnham 2009.

11 A.F. Moore, Song Means: Analysing and Interpreting Recorded Popular Song, Farnham - Burlington (VT) 2012. Warto dodać, że koncepcja persony muzycznej splata się często $\mathrm{z}$ badaniem persony rozumianej jako performatywny konstrukt prezentowany odbiorcom w różnych kontekstach (występ, nagranie, wywiad), jak np. Ziggy Stardust uosabiany na scenie i poza nią przez Davida Bowiego; zob. P. Auslander, op. cit.

12 A.F. Moore, op. cit., s. 179-184. 
autobiograficzny kontekst śpiewanego przez Niemena tekstu ${ }^{13}$. Podobnych przykładów jest wiele, ale równie wiele jest przykładów pęknięć czy przesunięć trzech poziomów znaczeń wspomnianych przez Moore’a. Dla nas interesujący okazał się przypadek kompozycji The Millionaire Waltz.

The Millionaire Waltz, piosenka napisana i skomponowana przez Freddiego Mercury'ego, znalazła się na płycie grupy Queen A Day At The Races (1976). Bywała co prawda postrzegana jako nieciekawa ${ }^{14}$, jednak obecnie częściej uznawana jest za ważną w twórczości grupy Queen ${ }^{15}$. Utwór The Millionaire Waltz zestawiany jest nawet z Bohemian Rhapsody: Nick Braae wskazuje podobieństwa układu formalnego, kontrasty części, instrumentację, połączenie rocka i nie-rocka, bogactwo brzmienia, a także pastiszowy charakter obydwu utworów ${ }^{16}$. Braae zauważa celnie, że The Millionaire Waltz jest przykładem stylotwórczej strategii Queen polegającej na zderzaniu „niskiej kultury rocka” z niskim rejestrem sztuki wysokiej („low” end of „,high culture”)

Jest w The Millionaire Waltz moment szczególny (3'25”), w którym Freddie Mercury, wykonujący tu główną partię wokalną, zaczyna śpiewać inaczej niż wcześniej: stosuje wyraźnie słyszalne „podjazdy” do kolejnych dźwięków melodii, korzysta $\mathrm{z}$ innej barwy głosu, którego nagranie dodatkowo sugeruje

13 Zob. R. Radoszewski, Czesław Niemen. Kiedy się dziwić przestanę... Monografia artystyczna, Warszawa 2004.

${ }_{14}$ „[The Millionaire Waltz] moves swiftly from the intricate to the awkward. Soon, it collapses under the weight of an unsound conceit, auto-annihilating like the best of Western culture”; W. Strick, Queen: Spirited, Impeccable, Silly, „Circus” 1977, Queen Archives, https://queenarchives.com/qa/xx-xx-1977-a-day-at-the-races-circus/ [dostęp 25.03.2020].

15 Zob. G. Purvis, Queen: Complete Works: (Revised and Updated), London 2019; B. Wawzenek, How Queen Attempted to Make a Sequel With „A Day at the Races”, 10.12.2016, Ultimate Classic Rock, https:/ultimateclassicrock.com/queen-day-at-the-races/?utm_source=tsmclip\&utm_medium $=$ referral [dostęp 25.03.2020].

${ }^{16}$ N. Braae, Queen's Classical Music References, 1973-76; or, Was Queen a Progressive Rock Band?, Dijon 2014 https://www.academia.edu/16285559/Queens_ classical_music_references_1973-76_or_was_Queen_a_progressive_rock_band [dostęp 29.03.2020].

17 Ibidem. Odróżniało to strategię Queen od działań innych progresywnych zespołów lat 70., traktujących odniesienia do sztuki wysokiej poważnie. 
bliskość mikrofonu (w konsekwencji - wrażenie bliskości nadawcy wobec odbiorcy), przede wszystkim zaś podaje tekst $\mathrm{z}$ wyraźnie odmiennym rodzajem akcentu, który intuicyjnie kojarzy się z niemiecką wymową języka angielskiego. Perspektywa persony muzycznej, a także ustalenia socjolingwistyczne pozwalają na przyjrzenie się temu fragmentowi i wskazanie, że jest on dowodem na złożoność przemyślanej kreacji artystycznej Freddiego Mercury'ego i zespołu Queen, nie tylko w The Millionaire Waltz, ale także w perspektywie ich - mówiąc językiem Allana F. Moore’a - idiolektu ${ }^{18}$. Aby to pokazać, obok wspomnianej wcześniej koncepcji persony muzycznej w rozumieniu Moore’a oraz tez trzeciej fali socjolingwistyki posłużymy się muzykologicznymi metodami analizy muzycznej (analiza nagrania z wykorzystaniem programu Sonic Visualiser, w szczególności nakładki Melodic Range Spectrogram i Peak Frequency Spectrogram, a także analiza słuchowa i formalna) oraz fonetycznej. Ze względu na brak dostępnej wyodrębnionej ścieżki wokalnej do The Millionaire Waltz, dzięki której można byłoby uniknąć zakłóceń spektrogramu powodowanych przez instrumenty muzyczne, analiza fonetyczna przeprowadzona jest przede wszystkim audytoryjnie (ze słuchu). Jednak omawiany fragment jest szczególny - tekst i linia wokalna są tu wyeksponowane poprzez wyciszenie akompaniamentu z wyjątkiem jedynie fortepianu. Oznacza to, że - choć obraz nie jest idealny z punktu widzenia analizy akustycznej - pewne wrażenia słuchowe można potwierdzić również w ten sposób. W tym celu zastosowano program Praat ${ }^{19}$.

Naszą refleksję nad The Millonaire Waltz zacznijmy od przekonania, że interesujący nas fragment kompozycji nosi znamiona stylizacji. Oto w partii śpiewanej przez Mercury'ego, obok wiodących słów pierwszoplanowego, śpiewającego bohatera piosenki, pojawia się wyraźnie wyodrębniony drugi głos, głos stylizowany, semantycznie pęknięty. Takie rozwiązanie przywodzi na myśl klasyczną koncepcję Michaiła Bachtina ${ }^{20}$, według którego nasza mowa wypełniona jest cudzymi słowami. Myśl tę można w pewnym sensie

18 Zob. A.F. Moore, op. cit., s. 166. Idiolekt u Moore'a to rodzaj stylu indywidualnego.

19 P. Boersma, D. Weenink, Praat: Doing Phonetics by Computer, wersja 6.0.40 [program komputerowy], 2018, http://www.praat.org.

${ }_{20}$ M. Bachtin, Speech Genres and Other Late Essays, transl. V.W. McGee, eds. C. Emerson, M. Holquist, Austin 1986. 
uznać za podsumowanie zjawiska, jakim jest stylizacja językowa. Natura tego zjawiska jest jednak złożona. Nikolas Coupland ${ }^{21}$ wyszczególnia następujące cechy charakterystyczne stylizacji:

a. wypowiedzi stylizowane stawiają sobie za cel odwzorowanie person, tożsamości i gatunków innych niż te, która są współobecne w danej sytuacji komunikacyjnej; odwzorowywane persony i gatunki wywodzą się z powszechnie znanych repertuarów tożsamościowych, nawet jeśli nie są odtwarzane w całości;

b. stylizacja jest metaforyczna, odrywa nadawcę od bezpośredniego kontekstu sytuacyjnego;

c. stylizacja jest refleksyjna, świadoma i wykreowana;

d. stylizacja wymaga akulturowanej publiczności, która potrafi odczytać i ocenić wartość semiotyczną odwzorowywanej persony lub gatunku;

e. stylizacja inicjuje proces porównania i reewaluacji (estetycznej i moralnej) prawdziwej oraz metaforycznej tożsamości, strategii oraz celów nadawcy, prowadząc do reewaluacji tożsamości i wartości odbiorców;

f. stylizacja przełamuje dane ramy sytuacyjne, nakładając na nie nową warstwę kontekstu społecznego i wprowadzając sprzeczne tożsamości i wartości - prowadzić to może do reewaluacji danych norm sytuacyjnych;

g. stylizacja jest kreatywna i odgrywana, a zatem wymaga odpowiednich zdolności; niektórzy wykonawcy są bardziej biegli w stylizacji niż inni;

h. wypowiedzi stylizowane często zawierają elementy emfatyczne i hiperboliczne; związane jest to z koniecznym zasygnalizowaniem przejścia do innej ramy sytuacyjnej oraz podkreślenia sprzecznych znaczeń;

i. stylizacja może być definiowana jako strategiczna nieautentyczność, co ma złożone skutki dla osobistego i kulturowego pojmowania autentyczności.

${ }^{21}$ N. Coupland, Style: Language Variation and Identity, Cambridge - New York 2007, s. 154. 
Szczególnym kontekstem sytuacyjnym, w którym zaobserwować można elementy stylizacyjne, są wystąpienia sceniczne (ang. staged performance lub high performance). W wystąpieniach scenicznych konstruowane moga być określone tożsamości społeczne, np. poprzez wykorzystanie skojarzeń i znaczeń związanych z określonym wariantem językowym (por. koncepcja indeksykalności znaczeńn ${ }^{22}$ ), co sprawia, że ten rodzaj aktywności charakteryzuje się dużym potencjałem metaspołecznym i metakulturowym. Repertuar znaczeń, z których korzystać mogą wykonawcy, jest szeroki i funkcjonuje niezależnie w społeczeństwie. Jednocześnie istotną rolę odgrywa tu charakter indywidualny danego artysty. Dochodzi zatem do swoistego napięcia między przekazywaną tradycją gatunku a indywidualnym rysem kreatywnym artysty ${ }^{23}$.

Wystąpienia sceniczne odznaczają się pewnymi cechami charakterystycznymi; niektóre z nich dotyczą aspektów fizycznych czy też technicznych, czasem jednak w naturalny sposób wiążą się z innymi kwestiami, w tym z przedstawionymi powyżej wyznacznikami stylizacji językowej. Jedną z cech stricte fizycznych jest na ogół wyraźne oddzielenie nadawcy i odbiorcy, artysty i publiczności. Miejscem tego pierwszego jest scena - współcześnie może nawet częściej: ekran, a do pewnego stopnia także nagranie audio, czyli scena audialna - zwykle będąca miejscem wydzielonym i fizycznie wywyższonym. Istotne problemy badawcze związane z językową analizą wystąpień scenicznych to ${ }^{24}$ :

a. tożsamość i sposób jej wyrażenia; odniesienia do grup docelowych na różnych poziomach, od ewokacji po przywłaszczenie;

b. refleksyjność: świadoma prezentacja form językowych dla wywołania zachwytu lub krytyki; cecha ta wiąże się ze szczególną rolą poetyckiej i metalingwistycznej funkcji języka poprzez skoncentrowanie na

22 M. Silverstein, Shifters, Linguistic Categories and Cultural Description, [w:] Meaning in Anthropology, eds. K.H. Basso, H.A. Selby, Albuquerque 1976; A. Agha, The Social Life of Cultural Value, „Language \& Communication” 2003, Vol. 23, No. 3-4.

23 A. Bell, The Guidebook to Sociolinguistics, Malden - Oxford 2014, s. 315.

${ }^{24}$ Ibidem; N. Coupland, Style: Language variation and identity, op. cit., s. 147148; A. Bell, A. Gibson, Staging Language: An Introduction to the Sociolinguistics of Performance, „Journal of Sociolinguistics” 2011, Vol. 15 (5), s. 555-572. 
formie i wielości jej znaczeń; z perspektywy fonetycznej zauważyć można, że powyższa intensywność prowadzić może do nienaturalnego wzmocnienia określonej cechy, tzw. overshoot ${ }^{25}$, ale też - do selektywności w tym względzie;

c. publiczność i relacja z nią - rola odbiorców jest ściśle określona w tym kontekście komunikacyjnym; odbiorcy mogą jednak mieć wpływ na formę wystąpienia;

d. autentyczność i różne oczekiwania w tym względzie, w zależności m.in. od gatunku (np. folk - autentyczność vs drag - strategiczna nieautentyczność);

e. gatunek i określony sposób wykonania z nim związany (np. jazz a $\left.\operatorname{rock}^{26}\right)$;

f. modalność: wymiary pozajęzykowe - muzyka, ruch sceniczny, scenografia - również mogą wyznaczać sposoby odczytania warstwy językowej.

Biorąc pod uwagę powyższe ustalenia, możemy stwierdzić, że od persony muzycznej Mercury’ego, która tworzy szkicowo zarysowanego głównego bohatera, odłącza się druga persona, która tworzy - językowo i wykonawczo - drugą postać (choć, być może, pokazuje jedynie drugie oblicze pierwszej persony muzycznej, oblicze żartobliwe, pastiszowe lub parodystyczne). Bez wątpienia jest to działanie świadome (nie ma odpowiednika w innych nagraniach Queen ${ }^{27}$ ), poprzez swoją jawność budujące quasi-teatralną nieautentyczność i przełamujące dotychczasową narrację słowno-muzyczną.

25 Zob. np. M. Konert-Panek, Overshooting Americanisation. Accent Stylisation in Pop Singing - Acoustic Properties of the BATH and TRAP Vowels in Focus, „Research in Language” 2017, No. 15 (4).

26 Por. np. M. Gradowski, M. Konert-Panek, How Covers Change Musical and Linguistic Sounds: A Case Study of „Love is Blindness" by U2 and Cassandra Wilson, [w:] Symphony and Song: The Intersection of Words and Music, eds. V. Kennedy, M. Gadpaille, Newcastle upon Tyne 2016, s. 171-185.

27 Mowa o wprowadzeniu niemieckiego akcentu. Samo pojawianie się obcych głosów i kolejnych person jest ważnym elementem idiolektu Queen; zob. M. Gradowski, M. Konert-Panek, O Queen II na dwa głosy. Słowno-muzyczne wokalizacje grupy Queen, [w:] Unisono w wielogłosie, cz. 3: Rock a korespondencja sztuk, red. R. Marcinkiewicz, Sosnowiec 2012, s. 46-69. 
Jest niczym kod pozwalający na odczytanie przekazu ukrytej treści tej kompozycji.

Niemiecki akcent przywodzi na myśl osobę Marlene Dietrich, będącą potencjalnym wzorem persony budowanej przez Mercury'ego jako kompozytora, wokalistę i interpretatora. Wynika to z faktu, że w roku 1976 (premiera płyty A Day At The Races) poprzez teledysk Bruce'a Gowersa do utworu Bohemian Rhapsody (znalazł się na wcześniejszej płycie A Night At The Opera) utrwalony został charakterystyczny wizerunek członków zespołu: cztery postaci ustawione $\mathrm{w}$ romb, ujęcie $\mathrm{z}$ dołu, na czarnym tle półcienie eksponują ostre rysy twarzy. Taki kadr pojawił się wcześniej na okładce płyty Queen II i jak twierdzi jej autor, Mick Rock, wzorowany był na zdjęciu Marlene Dietrich z filmu Shanghai Express. Rock przedstawił członkom grupy pomysł nawiązania do klasycznej fotografii Dietrich, na co Freddie Mercury miał entuzjastycznie zareagować: „Będę Marleną [...]. Cóż to za słodki pomysł!"28. Wizualne inspiracje wizerunkiem Marlene Dietrich są na okładce Queen II i w teledysku Bohemian Rhapsody czytelne, a nawiązanie do śpiewu Dietrich w The Millionaire Waltz wpisywałoby się w tę sieć relacji. Czy można jednak tak jednoznacznie określić personę w interesującej nas sekwencji tej piosenki? Aby odpowiedzieć na to pytanie, skupmy się przez chwilę na punkcie wyjścia do stworzenia tej szczególnej persony muzycznej: rzeczywistej postaci Marlene Dietrich.

Publiczny wizerunek Marlene Dietrich (właśc. Marie Magdalene Dietrich), niemiecko-amerykańskiej aktorki i piosenkarki, jest ważnym punktem odniesienia w popkulturowej mitologii, której stał się częścią. Szczególnie pamiętny jest w niej głos Dietrich: niski, lekko zachrypnięty, napowietrzony, bardzo rozpoznawalny i jako taki posiadający dużą siłę oddziaływania. „Gdyby nie miała nic prócz głosu, i tak by ci złamała serce" - powiedział swego czasu Ernest Hemingway ${ }^{29}$. Z tego też względu

${ }^{28}$ L.-A. Jones, Freddie Mercury. Biografia legendy, tłum. M. Kisiel-Małecka, Ł. Małecki, Wrocław 2012, s. 137.

29 „Life Magazine” 1952, cyt. za: A. Lawrence, Marlene Dietrich: The Voice as Mask, [w:] Dietrich Icon, eds. G. Gemünden, M.R. Desjardins, Durham (NC) 2007, s. 79. 
parodiowanie samego głosu/śpiewu Dietrich było w historii równie częste, jak w przypadku jej wizerunku ${ }^{30}$.

Równie istotne, jak wygląd i głos Dietrich, były jej zdolności językowe. Posługiwała się rodzimym niemieckim, francuskim, a także angielskim, co dawało różne odcienie jej kosmopolitycznie zabarwionego publicznego wizerunku. Jak zauważa Amy Lawrence, obcy akcent konstruuje znaczenia i generuje wrażenia: tajemniczości, obcości, inności ${ }^{31}$.

Ze względu na stylizację Mercury'ego w The Millionaire Waltz najbardziej interesuje nas język angielski w życiu Dietrich. Jak pisze Allan Bell ${ }^{32}$, artystka pochodziła $\mathrm{z}$ dobrej pruskiej rodziny, co wiązało się z surową dyscypliną, a także używaniem wysokoniemieckiego wariantu języka. Dietrich odebrała staranne wykształcenie, obejmujące także naukę języka angielskiego, choć po latach krytycznie oceniała jej poziom ${ }^{33}$. I rzeczywiście, to opanowanie języka, robiące wrażenie na gruncie niemieckim, w Stanach Zjednoczonych okazało się niewystarczające. Pierwsze wywiady Dietrich były niepewne, mówione z ciężkim akcentem. Pomimo opanowania angielskiego w późniejszych latach, pozostał on dla Dietrich zawsze językiem drugim. Jak wspomina córka artystki, Maria Riva, w angielszczyźnie jej matka zawsze czuła się cudzoziemką ${ }^{34}$.

Szczególny charakter stylizacji głosowych Marlene Dietrich analizowany jest również z perspektywy socjolingwistycznej. Bell ${ }^{35}$ odwołuje się do swojej teorii dotyczącej wariantywności stylistycznej (ang. style-shifting ${ }^{36}$, w której przedstawione są dwie strategie w tym obszarze. Nadawca może dostosowywać styl swojej wypowiedzi do odbiorcy (ang. Audience Design) lub też może, redefiniując zastaną sytuację i niejako odwracając

30 R. Curry, Madonna From Marilyn To Marlene - Pastiche And/Or Parody?, „Journal of Film and Video" 1990, Vol. 2.

31 A. Lawrence, op. cit., s. 82.

32 A. Bell, Falling in Love Again and Again: Marlene Dietrich and the Iconization of Non-native English, „Journal of Sociolinguistics” 2011, Vol. 15, Issue 5.

33 M. Dietrich, My Life, transl. S. Attanasio, London 1989, s. 27.

34 M. Riva, Marlene Dietrich, New York 1993, s. 70.

35 A. Bell, op. cit.

${ }^{36}$ Idem, Language Style as Audience Design Language, „Society” 1984, Vol. 13, No. 2. 
się od bezpośredniego odbiorcy, zwrócić się do nieobecnej (idealnej) grupy referencyjnej, stanowiącej punkt odniesienia (ang. Referee Design). Bell ${ }^{37}$ dokonuje porównania obcości (tj. niemieckości) akcentu Dietrich w utworze Falling in Love Again z roku 1930 (film Błękitny anioł) oraz z roku 1964 (wykonanie z Queen's Theatre w Londynie). Wyniki analizy porównawczej przedstawione są poniżej, wraz z podziałem na aspekty samogłoskowe, spółgłoskowe i prozodyczne. W nawiasach oznaczono formy pośrednie, a w ostatniej kolumnie - przykładowe słowa, obrazujące daną cechę.

Tab. 1. Liczba cech obcych (interferencji z języka niemieckiego) w wykonaniach utworu Falling in Love Again (Marlene Dietrich) z lat 1930 i $1964^{38}$

\begin{tabular}{llccl}
\hline \multicolumn{1}{c}{ Cecha fonetyczna } & N [1930] & N [1964] & \multicolumn{1}{c}{ Przykłady } \\
\hline Samogłoski & Pełna samogłoska zamiast & 10 & $2(+1)$ & wanted \\
& redukowanej [ə] & & & \\
& Monoftongizacja & 12 & $(3)$ & flame \\
& Skrócenie samogłoski & 2 & 1 & been \\
& Obniżenie samogłoski [3:] do [a] & 3 & 0 & burn \\
Spółgłoski & Niepoprawne zastosowanie & 5 & $(2)$ & wanted \\
& przydechu & & & \\
& Ubezdźwięcznienie [d] & 1 & 0 & around \\
& Afrykatyzacja [ð] & 1 & 0 & their \\
& Wargowo-zębowe [w] & $3(+1)$ & 0 & what \\
Prozodia & Brak welaryzacji [1] & $(+2)$ & $(2)$ & help \\
RAZEM & Zbyt równy rytm & 4 & 0 & I just can't help \\
\hline
\end{tabular}

Jak widać, wykonanie utworu z roku 1930 charakteryzuje się stosunkowo licznymi cechami wynikającymi z interferencji, w tym przypadku - wpływu języka niemieckiego na wymowę angielską. W wykonaniu z roku $1964 \mathrm{cech}$ tych jest zauważalnie mniej, jednak obcy akcent wciąż jest obecny. Bell interpretuje to zjawisko stylizacyjne jako przypadek kształtowania wypowiedzi ku punktowi odniesienia (ang. Referee Design), a nie ku bezpośredniemu odbiorcy (ang. Audience Design). Ponadto badacz stwierdza, że to właśnie obcobrzmiący niemiecki akcent - zwłaszcza w połączeniu

37 Idem, Falling in Love..., op. cit.

38 Na podstawie: ibidem, s. 640, 644. 
z niskim głosem ${ }^{39}$ Dietrich - stał się stopniowo wzorcem pierwszego głosu femme fatale w filmach dźwiękowych (tzw. urejestrowienie - ang. enregisterment $\left.{ }^{40}\right)$ i jej nieodłączną cechą charakterystyczną. Akcent ten był w tym czasie wielokrotnie odtwarzany, a czasem też parodiowany. Sama Dietrich stała się ikoną i - co widać w wykonaniu $\mathrm{z}$ lat 60. - punktem odniesienia dla samej siebie; to dlatego po latach wciąż usłyszymy w jej wymowie i wykonaniach scenicznych ślady akcentu niemieckiego.

Dla lepszego przedstawienia relacji „stylista - stylizacja - stylizowany” w piosence The Millionaire Waltz warto z perspektywy socjolingwistycznej spojrzeć na Freddiego Mercury’ego. Urodził się, jako Farrokh Bulsara, w roku 1946 w Stone Town na Zanzibarze - ówczesnej kolonii brytyjskiej w brytyjsko-indyjskiej rodzinie Parsów. Jako ośmiolatek Bulsara rozpoczął naukę w renomowanej szkole z internatem w Indiach, w której obowiązywał tradycyjny brytyjski system edukacyjny. W 1964 roku wraz rodziną przeprowadził się do Anglii, gdzie szybko zaadaptował się do nowego stylu życia, a jego późniejsza wymowa, pomimo być może początkowego wpływu indyjskiej odmiany języka angielskiego, określana była jako standardowo brytyjska, staranna czy wręcz arystokratyczna ${ }^{41}$. Jednak w śpiewie wymowa Mercury'ego, podobnie jak w przypadku wielu innych brytyjskich reprezentantów mainstreamowej muzyki popularnej, ma pewne cechy amerykańskie czy raczej - transatlantyckie ${ }^{42}$.

Przyjrzyjmy się interesującemu nas fragmentowi piosenki The Millionaire Waltz. Z punktu widzenia analizy socjolingwistycznej i stylistycznej

39 W oryginale pisze Bell o „baritone quality”, czyli „barytonowej jakości”, odnoszącej się do ogólnego wrażenia niskiego głosu. To mało precyzyjne, ponieważ baryton to głos męski, niski głos Dietrich to kontralt.

40 Zob. A. Agha, op. cit.

${ }^{41}$ L.-A. Jones, Freddie Mercury. Biografia definitywna, tłum. P. Lipszyc, Warszawa 1999, s. 42-69 i 296; idem, Freddie Mercury. Biografia legendy, op. cit., s. 37-47; L. Jackson, Freddie Mercury: The Biography, wydanie elektroniczne, Kindle 2011, lok. 134-135 i 156-161.

${ }^{42}$ M. Konert-Panek, „Under Pressure”: dwa głosy - dwa akcenty. Socjofonetyczny obraz czynników warunkujących styl wokalny w muzyce popularnej, [w:] Kultura rocka, cz. 2: Słowo - dźwięk-performance (1), red. J. Osiński, M. Pranke, P. Tański, Toruń 2016, s. 87-108. 
kluczowym fragmentem utworu jest moment, w którym wokalista tworzy personę mogącą kojarzyć się z Marlene Dietrich. Funkcjonują dwie wersje pisowni tego fragmentu. Zapis standardowy:

My fine friend - take me with you and love me forever

My fine friend - forever - ever

lub zapis z koperty pierwszego tłoczenia płyty, uwzględniający pewne szczególne aspekty fonetyczne, powtarzany później w oficjalnych wydaniach ${ }^{43}$ :

My fine friend - take me wiz you unt love me forever

My fine friend - forever - ever

W tym krótkim fragmencie występuje aż 8 z 10 kontekstów interferencyjnych analizowanych przez Bella ${ }^{44}$; brak jest jedynie kontekstu, w którym wystąpiłaby głoska [1] oraz samogłoska [3:], nie są one zatem uwzględnione $\mathrm{w}$ tabeli 2 . Zastosowany został także inny rodzaj interferencji w przypadku $[ð]$ - bardziej (stereo)typowy - dlatego też opis tej cechy został zmieniony. Jednak można to uznać za zjawisko tożsame, ponieważ dotyczy tego samego dźwięku docelowego: tak problematycznej, nie tylko dla Niemców, szczelinowej głoski zębowej. Co ciekawe - wbrew zapisowi unt i być może zamierzeniom (byłaby to typowa interferencja z języka niemieckiego) głoska zwarto-wybuchowa w śpiewie Mercury'ego jest dźwięczna, co wskazywać zdaje się na siłę rodzimej reguły fonologicznej, czyli brak ubezdźwięcznienia na końcu wyrazu w języku angielskim.

${ }^{43}$ Np. w: Queen, A Day at the Races, CD, 1976/2008, Biblioteka "Gazety Wyborczej”, TMM Polska/Planeta Marketing, Agora SA, lic. EMI Music Poland, s. 18. Na nagraniu Mercury śpiewa ostatnią frazę nieco inaczej: zamiast „ever” powtarza wcześniejsze „forever”.

44 A. Bell, Falling in Love..., op. cit. 
Tab. 2. Liczba cech obcych (stereotypowo kojarzonych z niemieckim akcentem języka angielskiego) w stylizowanym na Dietrich fragmencie utworu The Millionaire Waltz w wykonaniu Freddiego Mercury'ego

\begin{tabular}{llcl}
\hline \multicolumn{1}{c}{ Cecha fonetyczna } & N & \multicolumn{1}{c}{ Przykłady } \\
\hline \multirow{3}{*}{ Samogłoski } & Pełna samogłoska zamiast & & \\
& redukowanej [ə] & $1(+1)$ & and/unt \\
& Monoftongizacja & 0 & \\
& Skrócenie samogłoski & 0 & \\
& Niepoprawne zastosowanie & & \\
Spółgłoski & przydechu & 0 & \\
& Ubezdźwięcznienie [d] & 0 & and/unt \\
& Zastosowanie [z] zamiast [ð] & 1 & with \\
& Wargowo-zębowe [w] & 0 & \\
Prozodia & Zbyt równy rytm & \multicolumn{2}{c}{ take me with you and love } \\
RAZEM & & 1 & me \\
\hline
\end{tabular}

Przedstawiony poniżej obraz (spektrogram) frazy „take me with you” (il. 1) potwierdza obecność głoski [z] zamiast [ð] w wyrazie „with”. Wskazuje na to charakterystyczne widmo dźwięku - skupisko energii w wysokich częstotliwościach, typowe dla głoski szczelinowej dziąsłowej, które nie byłoby obecne w przypadku wariantu prawidłowego, czyli głoski szczelinowej zębowej ${ }^{45}$.

Analizowany fragment przypada w szczególnie interesującym momencie formy muzycznej. Aby to uzasadnić, warto przypomnieć, że The Millionnaire Waltz traktowany był przez zespół jako kontynuacja koncepcji kształtującej Bohemian Rhapsody. Chodzi tu o zestawianie części kontrastujących barwą, nastrojem i stylem, a także unikanie repetycji typowych dla form zwrotkowo-refrenowych przy jednoczesnym zachowaniu spójności utworu.

Utwór utrzymany jest w tonacji F-dur, lecz poszczególne segmenty (ponumerowane na il. 2) występują w tonacjach paralelnych lub pokrewnych. Dzięki takiemu zabiegowi zyskuje tonalna różnorodność utworu przy jednoczesnym zachowaniu jego harmonicznej spójności. W zachowaniu spójności pomaga też niepozorny motyw $(\mathrm{M})$, wprowadzony wpierw jako druga

${ }_{45}$ Zob. np. P. Ladefoged, Vowels and Consonants. An Introduction to the Sounds of Languages, Oxford - Malden 2001, s. 58. 
cząstka wstępu - I(M), a który następnie utrwala się na początku $\mathrm{A}(\mathrm{M})$ i powraca na końcu makroformy jako $\mathrm{I}(\mathrm{M})^{\prime}$ oraz $\mathrm{A}(\mathrm{M})^{\prime}$. Jest on ważny także dlatego, że obydwa warianty $\mathrm{A}(\mathrm{M})$ zawierają nawiązującą do tytułu frazę „make me feel like a millionaire".

Wśród innych zabiegów spajających formę badanego utworu znajduje się powtórzenie początkowych taktów melodii w częściach

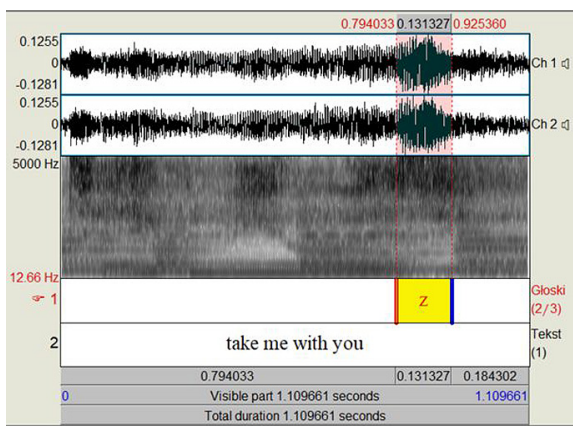

Il. 1. Spektrogram obrazujacy wymowe głoski szczelinowej w słowie „with” (Freddie Mercury) 2 i 3. Zmiana trybu (F-dur w 2 części i f-moll w 3 części) sprawia, że owe linie melodyczne na tle odmiennej harmonii różnią się wyrazem, jednak ich podobieństwo ujawnia się w analizie wyraźnie i stanowi dowód świadomego, głębokiego spajania formy prezentowanej odbiorcy jako kontrastująca. Powierzchniowa kontrastowość jest tu zachowana, zderzenia dominant nastrojowych układają się w czytelny ciąg: ,jasny” - „ciemny” - „jasny”. Klarowność tego podziału ciekawie rozmywa zakończenie segmentu 3 (mimo minorowego nastroju wcześniejszych taktów segment ten przechodzi na koniec w tryb durowy, by zaraz ustąpić miejsca minorowej sekwencji hardrockowej). Rozmywa go także właśnie segment „niemiecki”.

O ile w Bohemian Rhapsody są trzy główne płaszczyzny stylistyczne („ballada rockowa”, „opera”, „hard rock”), a punktem wyjścia jest rock, o tyle w The Millionaire Waltz następuje swoista apoteoza walca, pokazywanego przez pryzmat stylistyki „operetki” (spod znaku Gilberta i Sullivana), „wodewilu” oraz „wiedeńskich walców Straussa”46. Ten walc jest tu szczególny, ponieważ stanowi symbol muzycznej rozrywki sprzed pojawienia się bluesa, jazzu i kolejnych odnóg rock and rolla, które dziś kształtują pojęcie „muzyki popularnej”. Ta „dawna muzyka popularna” ma w sobie także semantyczny ładunek „mieszczaństwa”, co dodatkowo kontrastuje

46 Nick Braae (op. cit.) wskazuje konkretne nawiązanie - walc Johanna Straussa II Wiener Blut op. 354, do którego, jak twierdzi Braae, jest paralelnie zbudowana solówka Briana Maya pojawiająca się po segmencie hardrockowym. 
z rockowym obrazem twórczości grupy Queen, obecnym w The Millionaire Waltz także dosłownie. Podobnie jak w Bohemian Rhapsody występuje tu ekspresyjna, hardrockowa część środkowa, pełni ona jednak inną funkcję niż analogiczny fragment Bohemian Rhapsody. Tam stanowi przełamanie wtrąconej stylistyki quasi-operowej i zaznacza powrót do głównego języka kompozycji (rock), w The Millionaire Waltz z kolei jest chwilowym wyłomem, po którym powraca „walcowa” dominanta całości, gdzie dominują gitarowe imitacje brzmień orkiestry, quasi-operetkowe zaśpiewy i chórki, nie pojawia się rockowa perkusja, a całość utrzymana jest w nieortodoksyjnym dla muzyki rockowej (a koniecznym dla walca) metrum 3/4. Analizowana sekwencja z niemieckim akcentem jest jeszcze jednym wyłomem z przestrzeni „walca” (na marginesie: w tym aspekcie utwór The Millionaire Waltz jest bogatszy od Bohemian Rhapsody, częściej i skuteczniej dezorientuje słuchacza).

\section{Il. 2. Schemat formalny The Millionaire Waltz (program Variations Audio Timeliner)}

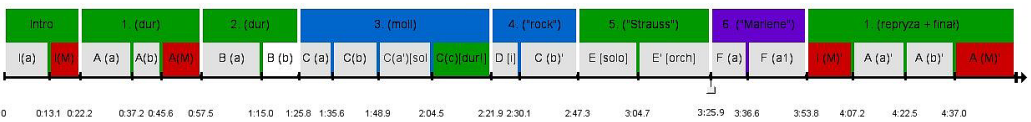

Tab. 3. Schemat formalny The Millionaire Walz $z$ kluczowymi zdarzeniami i planem tonalnym

\begin{tabular}{|c|c|c|c|c|}
\hline Sekcja & $\begin{array}{c}\text { Podział } \\
\text { sekcji }\end{array}$ & Czas & Zdarzenia & Tonacja \\
\hline Intro & $\begin{array}{l}\text { I (a) } \\
\text { I (M) }\end{array}$ & $\begin{array}{l}0^{\prime} 00^{\prime \prime}-0^{\prime} 13^{\prime \prime} \\
0^{\prime} 13^{\prime \prime}-0^{\prime \prime}\end{array}$ & $\begin{array}{l}\text { Fortepian i gitara basowa (temat } \\
\text { instr.) } \\
\text { Kulminacja: instr. motyw } \\
\text { łącznikowy }(\mathrm{M})\end{array}$ & F-dur \\
\hline 1. & $\begin{array}{l}\text { A (a) } \\
\text { A (b) } \\
\text { A (M') }\end{array}$ & $\begin{array}{l}0^{\prime} 21^{\prime \prime}-00^{\prime} 37^{\prime \prime} \\
0^{\prime} 37^{\prime \prime}-0^{\prime} 44^{\prime \prime} \\
0^{\prime} 44^{\prime \prime}-0^{\prime} 57^{\prime \prime}\end{array}$ & $\begin{array}{l}\text { "Bring out the charge of the love } \\
\text { brigade” } \\
\text { Głos solo - chórki; kontrapunkt } \\
\text { bg } \\
\text { Motyw łącznikowy }(\mathrm{M}) \text { - } \\
\text { orkiestracja gitarowa }\end{array}$ & F-dur \\
\hline 2. & B (a) & 0’58' - 1'24'” & Ballada - spokojniej niż 1 & F-dur \\
\hline
\end{tabular}




\begin{tabular}{|c|c|c|c|c|}
\hline Sekcja & $\begin{array}{c}\text { Podział } \\
\text { sekcji }\end{array}$ & Czas & Zdarzenia & Tonacja \\
\hline \multirow[t]{4}{*}{3.} & $\mathrm{C}(\mathrm{a})$ & 1'25'- 1'35"' & Ballada - spokojniej niż 2 & f-moll \\
\hline & $\mathrm{C}(\mathrm{b})$ & $1^{\prime} 35^{\prime \prime}-17^{\prime \prime}$ & & \\
\hline & $C\left(a^{\prime}\right)$ & $1^{\prime} 47^{\prime \prime}-2^{\prime} 04^{\prime \prime}$ & Partia solowa Briana Maya & f-moll - Es-dur \\
\hline & $\mathrm{C}(\mathrm{c})$ & $2^{\prime} 04^{\prime \prime}-2{ }^{\prime} 20^{\prime \prime}$ & $\begin{array}{l}\text { Orkiestracje - budowanie emocji } \\
\text { + tempo }\end{array}$ & \\
\hline \multirow[t]{2}{*}{4.} & D (i) & 2'21' - 2’29'” & „Hard rock”: Wstęp & f-moll \\
\hline & $C(b)$ & $2^{\prime} 29^{\prime \prime}-2^{\prime} 47^{\prime \prime}$ & $\begin{array}{l}\text { "Hard rock”: „Come back to me” } \\
\text { - riff }\end{array}$ & f-moll - Des-dur \\
\hline \multirow[t]{2}{*}{5.} & $\mathrm{E}(\mathrm{a})$ & $2^{\prime} 48^{\prime \prime}-3^{\prime} 05^{\prime \prime}$ & $\begin{array}{l}\text { "Strauss”: partia solowa } \\
\text { („Strauss" - cyt. Little Black Rain }\end{array}$ & As-dur \\
\hline & $\mathrm{E}\left(\mathrm{a}^{\prime}\right)$ & $3^{\prime} 05^{\prime \prime}-3^{\prime} 25^{\prime \prime}$ & $\begin{array}{l}\text { Cloud) } \\
\text { „Strauss": orkiestracje }\end{array}$ & As-dur - Es-dur \\
\hline \multirow[t]{2}{*}{6.} & F (a) & $3{ }^{\prime} 25^{\prime \prime}-3^{\prime} 35^{\prime \prime}$ & „Marlene” - cyt. „My fine & Es-dur \\
\hline & $F\left(a^{\prime}\right)$ & $33^{\prime \prime}-3^{\prime} 54^{\prime \prime}$ & friend" & $\begin{array}{l}\text { Es-dur - (B-dur) } \\
\text { - F-dur }\end{array}$ \\
\hline \multirow[t]{4}{*}{7.} & $\mathrm{I}(\mathrm{M})^{\prime}$ & $3^{\prime} 54^{\prime \prime}-4^{\prime} 07^{\prime \prime}$ & Powtórzenie sekcji 1 - & F-dur \\
\hline & A (a) & $4^{\prime} 07^{\prime \prime}-4^{\prime} 22^{\prime \prime}$ & rozbudowana orkiestracja & \\
\hline & $A(b)^{\prime}$ & $4^{\prime} 22^{\prime \prime}-4^{\prime} 37^{\prime \prime}$ & & \\
\hline & $\mathrm{A}(\mathrm{M})^{\prime}$ & $4^{\prime} 37^{\prime \prime}-4^{\prime} 55^{\prime \prime}$ & & \\
\hline
\end{tabular}

Postawmy pytanie: czy w świetle powyższych rozważań socjolingwistycznych analiza muzykologiczna może pomóc w uznaniu, że persona zbudowana przez Mercury'ego to Marlene Dietrich? Fani i dziennikarze tak to odbierają: Mercury śpiewa jak Dietrich ${ }^{47}$. Po gruntownej kwerendzie odnosimy wrażenie, że to przypisanie persony do dźwięków jest konsekwencją popularności wspomnianych wcześniej elementów wizualnej identyfikacji zespołu. W dostępnych źródłach dotyczących Freddiego Mercury’ego i grupy Queen Marlene Dietrich w zasadzie nie pojawia się poza wspomnianym wcześniej kontekstem. Bywa on rozszerzany o autocytat (wykorzystanie ustawienia z okładki Queen II i teledysku Bohemian Rhapsody w wideoklipie do One Vision), pojawiają się niewielkie nawiązania (Freddie Mercury chciał, aby zdjęcie na okładkę płyty The Game zrobił fotograf George Hurell, autor portretów gwiazd - w tym Marlene Dietrich - złotej ery Hollywood), ale

${ }^{47}$ Zob. dyskusja na forum fanów Queen: http://www.queenzone.com/forums/652985/song-appreciation-your-thoughts-on-millionaire-walts.aspx [dostęp 30.03.20202]. 
poza tymi drobnymi rozszerzeniami wszystkie wzmianki o Dietrich odsyłają do momentu, w którym Mick Rock przyniósł na sesję Queen II słynną fotografię aktorki. Tak jak gdyby chodziło tylko o to jedno zdjęcie, co z kolei postawiłoby pod znakiem zapytania pojawiające się w biografiach informacje o głębszej inspiracji Marlene Dietrich (odesłanie do jednej anegdoty Micka Rocka wydaje się niewystarczającym dowodem).

$\mathrm{Z}$ tego względu interpretacja persony pojawiającej się w The Millionaire Waltz ma duże znaczenie dla doprecyzowania kontekstów kulturowych twórczości Queen. Analiza nagrania tego utworu daje dwa argumenty na korzyść tezy, że w istocie identyfikowanie persony muzycznej jako „Marlene Dietrich” może być zasadne. Pierwszy z nich dotyczy pojawiających się w tym fragmencie manier wykonawczych: są to przede wszystkim wspomniane wcześniej przerysowane „podjazdy”, glissanda do właściwej wysokości dźwięku, stosowane tu przez Mercury’ego. Widać to wyraźnie w spektrogramie nagrania frazy „My fine friend” (il. 3). Poziome linie dźwięków o ustalonej wysokości, precyzyjnym ataku i stabilnej intonacji (partia fortepianu) stanowią czytelny wizualnie punkt odniesienia dla falistej maniery Mercury'ego, stosowanej często przez Marlene Dietrich.

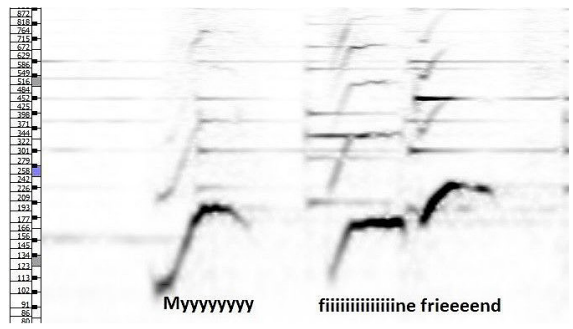

Il. 3. Sonic Visualiser: Melodic Range Spectrogram przedstawiajaćcy intonacje frazy "My fine friend"

Drugi argument także dotyczy maniery wykonawczej. W śpiewie Mercury'ego obok właściwych dźwięków pojawiają się nadreprezentowane szumy wydychanego powietrza (il. 4). Taki zabieg „napowietrzania” głosu jest również często słyszalny u Marlene Dietrich i może być argumentem za tą konkretną stylizacją.

Jak wspomniano we wstępie, wypowiedzi stylizowane za cel stawiają sobie odwzorowanie person, tożsamości i gatunków innych niż te, która są współobecne w danej sytuacji komunikacyjnej - i z takim właśnie przypadkiem mamy tu do czynienia. W analizowanym fragmencie Freddie Mercury daje wystarczająco dużo językowo-muzycznych danych, by przy uwzględnieniu pozostałych kontekstów dać możliwość interpretacji wykreowanej persony jako postaci Marlene Dietrich. W tym wariancie Mercury 


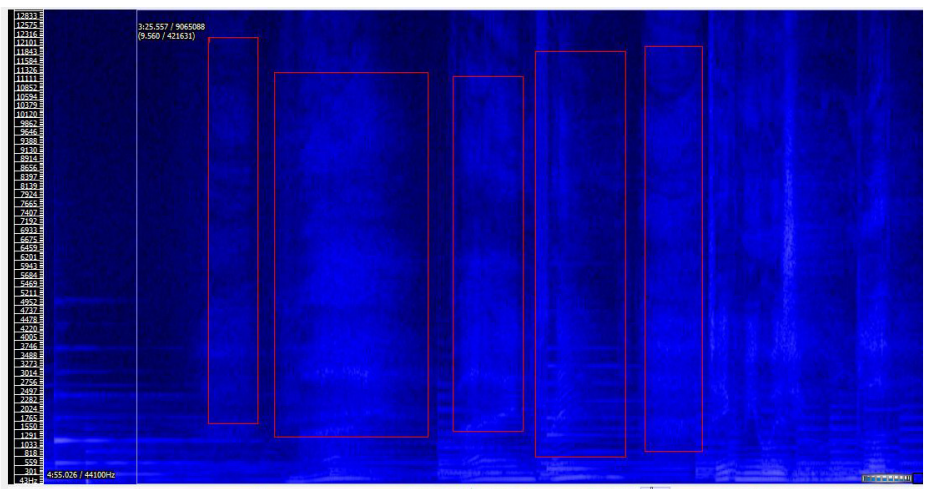

Il. 4: Sonic Visualiser: Peak Frequency Spectrogram przedstawiajacy oddechy (ramki skrajne) i widmo dźwięków stów „My fine friend” (ramki środkowe)

stylizuje się na nią wokalnie i kształtuje swą wypowiedź ku punktowi od niesien ia (ang. Referee Design), nieobecnemu w zastanej sytuacji komunikacyjnej. Sam ten fakt niejako potwierdza po raz kolejny ikoniczność Dietrich - zaistnienie tej persony wśród powszechnie znanych repertuarów tożsamościowych, inspirujących, obecnych i wciąż odtwarzanych w różnych kontekstach kulturowych.

Zauważyć jednak należy, że zastosowane w tym celu cechy fonetyczne są selektywne, a w jednym wypadku (końcowy dźwięk słowa „and”) można wręcz mówić o zjawisku tzw. undershoot - niedostatecznego, względem zamierzeń, odtworzenia cechy fonetycznej. Na poziomie fonetycznym stylizacja ta nie jest zatem bardzo dokładna, a mimo to - jest skuteczna. Powodem tej skuteczności wydaje się odpowiedni dobór imitowanych cech obcego akcentu Dietrich, w szczególności - wymowa końcowej głoski w „with” ([z]) oraz imitowany aspekt prozodyczny (zbyt równy rytm). Obie cechy są wyraźne i charakterystyczne, a zamiana potencjalnej afrykatyzacji w wyrazie „with” (por. tab. 1) na [z] wydaje się opcją zarówno bardziej (stereo)typową, jak i spektakularną; można widzieć tę zmianę jako rodzaj hiperbolizacji.

Jednocześnie można interpretować wyżej wskazaną selektywność jako sposób uzyskania efektu subtelności, uniknięcie jawnej parodii, a zarazem utrzymania indywidualnego charakteru Mercury'ego (por. wstęp i kwestię napięcia między odwzorowaniem a oryginalnością). Nawiązań i imitacji jest 
tu zatem tylko tyle, ile konieczne dla uzyskania określonego efektu, a równowaga między odtwarzaniem a innowacją pozostaje zachowana. Co więcej, stwarza to okazję do szerszej interpretacji tych słowno-muzycznych gestów. Dane niewystarczające do jednoznacznego ustalenia tożsamości persony otwierają swoją wieloznaczność. W tym miejscu przypomnieć należy, że Mercury fascynował się przedwojennym niemieckim kabaretem, przyjaźnił z Lisą Minnelli, którą cenił m.in. za rolę w uwielbianym przez siebie filmie Kabaret (a więc - znów - niemiecki kabaret i wspólna z personą Marlene Dietrich przestrzeń znaczeniowa).

Inne zagadnienie wiąże się z celowością zbudowania persony. To, że pojawia się ciąg znaczeniowy możliwy do uchwycenia przez słuchaczy o różnych kompetencjach stylistycznych (od ogólnego: „diva” - „niemiecka diva”, do szczegółowego: „Marlene Dietrich”), w świetle wcześniejszych ustaleń nie budzi wątpliwości. Działanie to przynosi wielorakie, nakładające się na siebie znaczenia.

Po pierwsze - humor, żart. Twórczość grupy Queen zawiera w sobie głębokie pokłady brytyjskiego humoru, który najłatwiej zestawić z jednej strony z kabaretowymi i wodewilowymi inspiracjami muzycznymi, z drugiej - $\mathrm{z}$ estetyką kampu. The Millionaire Waltz jest tego dobrym przykładem, a tropów do inteligentnej zabawy jest kilka: zespół rockowy sięgający po staroświeckiego walca (raz orkiestrowo bogatego, innym razem - jak we wstępie czy „straussowskiej” partii solowej Briana Maya - banalnego), przerysowanie ekspresyjne (ekstatyczne chórki), treść (tytułowy milioner to osoba bogata... wiosenną miłością), generująca humor nieciągłość zestawień (Strauss i hard rock). Humorystyczny charakter ma też solo gitarowe, które czytelnie nawiązuje do piosenki Richarda i Boba Shermanów Little Black Rain Cloud z filmu Walta Disneya Winnie the Pooh and the Honey Tree (1966), pojawiającej się w wersji instrumentalnej także w Winnie the Pooh and the Blustery Day (1968): „dorosły” rock sąsiaduje $\mathrm{z}$ „dziecięcym” walczykiem $^{48}$. W tym świetle persona muzyczna divy/Marlene jawi się jako kolejna nieciągłość między oczekiwaniami odbiorcy (zespół rockowy gra

48 Brian May mógł znać te filmy z młodych lat, mógł też przypomnieć sobie o nich w 1976 roku (sesje trwały od lipca do listopada): w marcu 1977 na ekrany kin wszedł film The Many Adventures of Winnie the Pooh zawierający m.in. obydwa wspomniane filmy krótkometrażowe. Niewykluczone, że do Maya mogły 
muzykę rockową) a przedstawionym materiałem (brytyjski zespół rockowy gra i śpiewa muzykę z niemieckiego kabaretu). W tym kontekście ciekawą kwestią jest zastosowanie przez Mercury'ego brytyjskiego wariantu wymowy słowa „danced” [da:nst] we frazie: „Do you remember, my love // How we danced and played?”. Mogłoby się wprawdzie wydawać, że rzecz to naturalna w przypadku brytyjskiego wokalisty, jednak - jak wspomniano już wyżej - w przypadku zespołu Queen (a także wielu innych wykonawców brytyjskich), mamy na ogół do czynienia z amerykańską wymową tej cechy fonetycznej, określanej mianem BATH-TRAP split; tu oznaczałoby to formę [dænst]. Jak wynika $\mathrm{z}$ badań Moniki Konert-Panek ${ }^{49}$, poziom amerykanizacji tej cechy w analizie przekrojowej, obejmującej pięć albumów grupy Queen, jest relatywnie stały i wysoki: wynosi od 70\% do 100\%. Zastosowanie wariantu tak charakterystycznie brytyjskiego i zdecydowanie rzadszego w mainstreamowej muzyce popularnej wiązać można z jednej strony ze staroświeckim charakterem samego walca, a z drugiej - z lekkim przymrużeniem oka, kabaretem i figlarnością ${ }^{50}$.

Po drugie - nostalgia. Persona divy/Marlene korzysta ze znaczeń tego, co dawne, co idzie w parze $\mathrm{z}$ innymi elementami dzieła. Walc (XIX wiek, Wiedeń, bal, szlachetna rozrywka), Little Black Rain Cloud (dzieciństwo, naiwność, niewinność) oraz wiosenna miłość (młodość, fascynacja, pełnia życia). Podobnie jak interesująca nas figura divy/Marlene elementy te nabierają kalejdoskopowej migotliwości i obok potencjału humorystycznego mają równie duży potencjał generowania uczucia ciepłej nostalgii.

Trzeci aspekt dotyczy kategorii „bogactwa”. Tekst utworu nie kryje, że śpiewający bohater chce dzięki wiosennemu przypływowi miłosnych uczuć poczuć się jak milioner. W igraniu między znaczeniem dosłownym (bogactwo materialne) a metaforycznym (bogactwo uczuciowe) figura divy/Marlene z jednej strony pomaga, wprowadzając pierwiastek glamour,

dotrzeć informacje o planowanej premierze, które przywołały wspomnienie dawnej melodii.

49 M. Konert-Panek, „Under Pressure”..., op. cit., s. 102.

50 Zob. interpretacja mocnego brytyjskiego akcentu Iana Dury'ego w świetle inspiracji tradycją komediową music-hall w artykule Petera Trudgilla: Acts of Conflicting Identity. The Sociolinguistics of British Pop-Song Pronunciation, [w:] On Dialect. Social and Geographical Perspectives, ed. P. Trudgill, Oxford 1983. 
z drugiej zaś - poprzez bliźniaczy konstrukt kobiety-wampa - wspiera budowanie wagi miłosnych znaczeń. Pomaga w tym bogata orkiestracja gitarowa, krystalizująca wrażenie splendoru wiedeńskiej sali balowej (Strauss!).

Last but not least, perspektywa genderowa. Grupa Queen, a w szczególności jej frontman, często stosowała strategiczną nieautentyczność. Przywołanie w The Millionaire Waltz innej postaci wydaje się na miejscu, wkomponowuje się w wizerunek grupy i samego Freddiego Mercury'ego. Relacja - męskie/damskie, love-miłość / love-seks (Marlene Dietrich jako wamp / symbol seksu), dedykacja utworu kierowana do menadżera Johna Reida, wprowadzająca homoerotyczny kontekst ${ }^{51}$, wejście w kostium $d r a g$ queen (Freddie jako Marlene), estetyka kampu - wszystko to łączy się z innymi działaniami Mercury’ego. Jak zauważa Ileana Botescu-Sireţeanu, Mercury powiedział Rockowi, że „będzie Marleną” półżartem: „W tym czasie zmagał się on z własną seksualnością, a jednocześnie - pozostając w heteroseksualnym związku z Mary Austin - nie mógł się do tej walki przyznać nawet przed samym sobą; dylemat ten przeniósł zatem do sfery muzycznej i wizualnej swych występów"52. A także do działań słowno-muzycznych - możemy dodać po analizie kilkunastosekundowego fragmentu jego piosenki The Millionaire Waltz.

\section{Bibliografia}

Asif Agha, The Social Life of Cultural Value, „Language \& Communication” 2003, Vol. 23, No. 3-4.

Philip Auslander, Musical Persona: The Physical Performance of Popular Music, [w:] The Ashgate Research Companion to Popular Musicology, ed D.B. Scott, Ashgate Publishing, Farnham 2009.

Michaił Bachtin, Speech Genres and Other Late Essays, transl. V.W. McGee, eds. C. Emerson, M. Holquist, University of Texas Press, Austin 1986.

51 Warto przypomnieć, że John Reid, menadżer Queen, ale też Eltona Johna, był w tamtym czasie jedną z najbardziej wyrazistych postaci środowiska LGBT.

52 I. Botescu-Sireţeanu, Queer in Queen: Camp Aesthetics and Queer Performativity in Queen's Music Videos, „Bulletin of the Transilvania University of Braşov. Series IV: Philology \& Cultural Studies” 2019, Vol. 1, s. 94. 
Joan C. Beal, „You're not from New York City, you're from Rotherham”: Dialect and Identity in British Indie Music, „Journal of English Linguistics” 2009, Vol. 37, No. 3.

Allan Bell, Falling in Love Again and Again: Marlene Dietrich and the Iconization of Non-native English, „Journal of Sociolinguistics” 2011, Vol. 15, Issue 5.

Allan Bell, The Guidebook to Sociolinguistics, Wiley-Blackwell, Malden - Oxford 2014.

Allan Bell, Language Style as Audience Design Language, „Society” 1984, Vol. 13, No. 2.

Allan Bell, Andy Gibson, Staging Language: An Introduction to the Sociolinguistics of Performance, „Journal of Sociolinguistics” 2011, Vol. 15, No. 5.

Paul Boersma, David Weenink, Praat: Doing Phonetics by Computer, wersja 6.0.40 [program komputerowy], 2018, http://www.praat.org.

Ileana Botescu-Sireţeanu, Queer in Queen: Camp Aesthetics and Queer Performativity in Queen's Music Videos, „Bulletin of the Transilvania University of Braşov. Series IV: Philology \& Cultural Studies” 2019, Vol. 1.

Nick Braae, Queen's Classical Music References, 1973-76; or, Was Queen a Progressive Rock Band?, University of Dijon, Dijon 2014, https://www. academia.edu/16285559/Queens_classical_music_references_1973-76_or_ was_Queen_a_progressive_rock_band.

Anna Chęćka-Gotkowicz, Persona (non) grata: czy muzyka absolutna potrzebuje narratora?, „Aspekty Muzyki” 2013, nr 3.

Edward T. Cone, The Composer's Voice, University of California Press, Berkeley 1974.

Nikolas Coupland, Style: Language Variation and Identity, Cambridge University Press, Cambridge - New York 2007.

Ramona Curry, Madonna From Marilyn To Marlene - Pastiche And/Or Parody?, "Journal of Film and Video" 1990, Vol. 2.

Marlene Dietrich, My Life, transl. S. Attanasio, Weidenfeld, London 1989.

Penelope Eckert, Meaning and Linguistic Variation. The Third Wave in Sociolinguistics, Cambridge University Press, Cambridge 2018.

Penelope Eckert, Variation and the Indexical Field, "Journal of Sociolinguistics” 2008, Vol. 12, No. 4.

Simon Frith, Sceniczne rytuały. O wartości muzyki popularnej, tłum. M. Król, WUJ, Kraków 2011.

Mariusz Gradowski, Monika Konert-Panek, How Covers Change Musical and Linguistic Sounds: A Case Study of „Love is Blindness” by U2 and Cassandra 
Wilson, [w:] Symphony and Song: The Intersection of Words and Music, eds. V. Kennedy, M. Gadpaille, Cambridge Scholars Publishing, Newcastle upon Tyne 2016.

Mariusz Gradowski, Monika Konert-Panek, O Queen II na dwa głosy. Słownomuzyczne wokalizacje grupy Queen, [w:] Unisono w wielogłosie, cz. 3: Rock a korespondencja sztuk, red. R. Marcinkiewicz, GAD Records, Sosnowiec 2012.

Laura Jackson, Freddie Mercury: The Biography, wydanie elektroniczne, Kindle 2011. Lesley-Ann Jones, Freddie Mercury. Biografia definitywna, tłum. P. Lipszyc, Alfa, Warszawa 1999.

Lesley-Ann Jones, Freddie Mercury. Biografia legendy, tłum. M. Kisiel-Małecka, Ł. Małecki, Wydawnictwo Dolnośląskie, Wrocław 2012.

Peter Kivy, Antithetical Arts: On the Ancient Quarrel Between Literature and Music, Oxford University Press, Oxford 2009.

Karolina Kolinek-Siechowicz, Od teorii muzycznej persony do muzycznego personalizmu, [w:] Peter Kivy i jego filozofia muzyki, red. A. Chęćka-Gotkowicz, M. Jabłoński, Wydawnictwo PTPN, Poznań 2015.

Monika Konert-Panek, Overshooting Americanisation. Accent Stylisation in Pop Singing - Acoustic Properties of the BATH and TRAP Vowels in Focus, „Research in Language” 2017, Vol. 15, No. 4.

Monika Konert-Panek, „Under Pressure”: dwa głosy - dwa akcenty. Socjofonetyczny obraz czynników warunkujacych styl wokalny w muzyce popularnej, [w:] Kultura rocka, cz. 2: Słowo - dźwięk - performance (1), red. J. Osiński, M. Pranke, P. Tański, WN UMK, Toruń 2016.

Peter Ladefoged, Vowels and Consonants. An Introduction to the Sounds of Languages, Blackwell Publishers, Oxford - Malden 2001.

Amy Lawrence, Marlene Dietrich: The Voice as Mask, [w:] Dietrich Icon, eds. G. Gemünden, M.R. Desjardins, Duke University Press, Durham NC 2007.

Jerrold Levinson, Music, Arts \& Metaphysics. Essays in Philosophical Aesthetics, Cornell University Press, Ithaca (NY) - London 1990.

Allan F. Moore, Song Means: Analysing and Interpreting Recorded Popular Song, Ashgate Publishing, Farnham - Burlington (VT) 2012.

Georg Purvis, Queen: Complete Works: (Revised and Updated), Titan Books, London 2019. 
Roman Radoszewski, Czesław Niemen. Kiedy się dziwić przestanę... Monografia artystyczna, Iskry, Warszawa 2004.

Maria Riva, Marlene Dietrich, Alfred A. Knopf, New York 1993.

Jenefer Robinson, Deeper than Reason, Emotion and its Role in Literature, Music, and Art, Clarendon Press, Oxford 2005.

Michael Silverstein, Shifters, Linguistic Categories and Cultural Description, [w:] Meaning in Anthropology, eds. K.H. Basso, H.A. Selby, University of New Mexico Press, Albuquerque 1976.

Wesley Strick, Queen: Spirited, Impeccable, Silly, „Circus” 1977, Queen Archives, https:/queenarchives.com/qa/xx-xx-1977-a-day-at-the-races-circus/.

Peter Trudgill, Acts of Conflicting Identity. The Sociolinguistics of British Pop-Song Pronunciation, [w:] On Dialect. Social and Geographical Perspectives, ed. P. Trudgill, Blackwell, Oxford 1983.

Bryan Wawzenek, How Queen Attempted to Make a Sequel With "A Day at the Races", 10.12.2016, Ultimate Classic Rock, https://ultimateclassicrock. com/queen-day-at-the-races/?utm_source=tsmclip\&utm_medium=referral.

\section{Źródła fonograficzne}

Queen, A Day at the Races, CD, 1976/2008, Biblioteka „Gazety Wyborczej”, TMM Polska/Planeta Marketing, Agora SA, lic. EMI Music Poland.

\section{Marlene Dietrich and The Millionaire Waltz by Queen. Linguistic and Musical Constructions of Persona in Popular Music}

The paper adopts an interdisciplinary research perspective on popular music on the basis of the song The Millionaire Waltz by Queen. The main focus is placed on the key part of the song: the fragment in which the vocalist, Freddie Mercury, adopts German accent. This fragment is analyzed with reference to the concept of persona, both musical (A.F. Moore) and linguistic - as emphasized in the theory of style-shifting (A. Bell) and the third wave in sociolinguistics (P. Eckert). The analysis concentrates on the problem of the split between the performer, persona and protagonist in the song, as well as the artistic tension between projection and originality. The applied research tools and methods (Praat and Sonic Visualiser programs, as well as formal and auditive analises) lead to the conclusion confirming the popular impression according to which Freddie Mercury imitates Marlene Dietrich 
in the analyzed song. His performance may be theorized as an example of Referee Design. Yet, some linguistic and musical aspects of this stylization suggest that this interpretation is not unambiguous. The complex character of the persona created by Mercury may be seen as an asset which gives rise to a wide spectrum of meanings (Marlene - German diva-diva), corresponding with Queen's artistic tropes (stylization, cabaret, operetta, contrast, humor, nostalgia, queer) and maintaining the balance between reproduction and innovation.

Keywords: musicology, persona, popular music, sociophonetics, stylization 